Vol. 2, No. 4, pp. 290-301, (December 2021)

DOI: 10.21608/aujes.2021.99317.1044

Aswan University Journal of Environmental Studies (AUJES)

Online ISSN: 2735-4237, Print ISSN: 2735-4229

Journal homepage: https://aujes.journals.ekb.eg/

E-mail: AUJES@aswu.edu.eg

Original research

\title{
Determination of heavy metals in preserved milk using microwave digestion and atomic absorption spectroscopy
}

\author{
Adela Elssady Mohamed ${ }^{1}$, M. N. Rashed ${ }^{*}$, Mohamed M. Aboelhassn ${ }^{2}$ \\ 1. Chemistry Department, Faculty of Science, Aswan University, Egypt \\ 2. Central laboratory at Qena, directorate of health. Ministry of health
}

Received: 3/10/2021

Accepted: 20/11/2021

(c) Unit of Environmental Studies and Development, Aswan University

\begin{abstract}
:
Heavy metals $\mathrm{Cd}, \mathrm{Cu}, \mathrm{Fe}, \mathrm{Pb}$ and $\mathrm{Zn}$ were determined in preserved milk from different companies to study the effect of preservation time in its metal contents. Milk samples of two companies (Brand1 and Brand2) were collected from different markets at Qena city,Egyp. The milk samples were selected at three validity time stages, first stage (the start of validity date),second stage ( the middle of validity date)and the third stage (the expiry date). For the determination of metal contents, the milk samples were subjected to the optimized microwave digestion method using $\mathrm{HNO}_{3}$ and $\mathrm{H}_{2} \mathrm{O}_{2}$. Heavy metal ( $\mathrm{Zn}, \mathrm{Fe}, \mathrm{Cu}, \mathrm{Pb}, \mathrm{Cd}$ ) concentrations were determined by atomic absorption spectrophotometer. The results obtained showed that metal concentrations in the milk were in the order $\mathrm{Zn}>\mathrm{Fe}>\mathrm{Cu}>\mathrm{Pb}>\mathrm{Cd}$. According to the permissible limits of heavy metals recommended by Egyptian Standard 7136, the maximum concentration of the studied metals in all samples did not exceed the permissible limits at the three stages.
\end{abstract}

Keywords: heavy metals, pollution, milk, preservation, microwave digestion.

\section{1- INTRODUCTION}

During the last decades, the rise of food production and development of processing technology has increased, which lead to the chances of food contamination with environmental pollutants, especially heavy metals. The toxicity of heavy metals to humans is the result of exposure to long term contamination in our environment (Ziarati et al., 2012). Due to the increase in food industrial activity, the heavy metals pollution to human has grown widely throughout the world (Alimardan et al., 2016). Heavy metals cause serious human health problems such as nervous system disorders, types of cancers, neurological disorders, renal failure, genetic mutations, respiratory disorders, infertility, cardiovascular, and immune system weakening (Azami et al., 2017). Lead causes several diseases like damage to the kidney and liver, central nervous system disorders, anemia, the immune system, the genital system, the digestive tract and various cancers (Alimardan et al., 2016).

Corresponding author*: E-mail address: mnrashed@ hotmail.com 
Cadmium is carcinogenic in the lungs and prostate and cause the tumor develops. It accumulates in tissues of the liver and kidney, causing anemia, and increase in blood pressure (Raikwar et al., 2008). Food safety is an important aspect of a nation's economic stability, and is a scientific discipline describing handling, preparation and storage of food in ways that prevent food borne illness. The safety of the food chain can be broken by both contamination and adulteration of food in different steps of the cycle. Unsafe food causes many acute and life-long diseases, ranging from diarrheal diseases to various forms of cancer (Mridha, 2013).

Food is the main source of uptake of toxic trace metals for human being. The World Health Organization (WHO) has recognized food contamination as a global challenge in several documents and reports (Fukuda, 2015). Therefore, consumption of contaminated foods causes illness in millions of people and many die as a result of it. Intentional food contamination refers to the deliberate addition of a harmful or poisonous substance to food products. A food contaminant can be biological, chemical or physical in nature, with the former being more common. These contaminants have several routes throughout the supply chain to enter and make a food product unfit for consumption. Also, it can originate from a number of different sources, such as naturally occurring toxicants, bacterial contamination, the improper use of pesticides and veterinary drugs, and the addition of chemicals during processing techniques, as well as emerging chemical hazards. Detection of food contaminants is essential for human health protection and also for controlling the global trading of contaminated food products (Viswanathan et al., 2009).

The 49th meeting of FAO discussed the limits for arsenic, lead and other heavy metals in food additive specifications, and concluded that the validity of the limit test for heavy metals (expressed as lead) was compromised due to lack of specificity and potential loss of metals and arsenic during the dry-ashing procedure (FAO/WHO, 1999). At the same meeting, a general limit of $2 \mathrm{mg} / \mathrm{kg}$ for lead was adopted. For additives to be consumed in substantial amounts, a limit of $1 \mathrm{mg} / \mathrm{kg}$ or lower would be proposed. A higher level of e.g. $5 \mathrm{mg} / \mathrm{kg}$ would require evidence that the lead level could not be reduced to these levels (WHO, 2000). The $53^{\text {rd }}$ meeting 3 of decided to review and to replace the limit test for heavy metals with limits for individual metals of concern in all existing specifications. (FAO/WHO 2000a, b).

Several studies about heavy metals in milk and milk products were published. Elbagermi et al. (2020) studied the concentrations of major metals ( $\mathrm{Fe}, \mathrm{Cu}, \mathrm{Zn}, \mathrm{Co}, \mathrm{Ni}, \mathrm{Cr}, \mathrm{Pb}, \mathrm{Cd}$, and $\mathrm{Mn}$ ) in eleven long life and pasteurized milk samples available in Misurata city markets and to find out whether the levels of these metals are lower than the recommended concentrations demanded for human consumption; particularly children, and furthermore to attain the extent of contamination.

Sarsembayeva et al. (2020) studied heavy metal levels in milk and fermented milk products produced in the Almaty region, Kazakhstan and found that The contents of cadmium, lead, and arsenic in all raw materials and food products did not exceed the maximum permissible concentrations. Francisco et al. (2021) studied the presence of heavy metals in raw bovine milk from Machachi, Ecuador and found that all the samples analyzed showed lead levels, with an average of $0.208 \mathrm{mg} / \mathrm{kg}$, of which contain levels higher than the maximum allowed by the Ecuadorian Technical Standard (NTE) INEN $9(0.02 \mathrm{mg} / \mathrm{kg}$ ), while $\mathrm{Hg}$ and As were below the limit allowed by the Codex Alimentarius $(0.01 \mathrm{mg} / \mathrm{kg})$ in food in general.

Shahriar et al. (2014) studied concentration of copper and lead in market milk and milk products of Bangladesh, and found that, most of all milk samples contain copper and lead. The content of 
copper in most of all raw milk and milk products were in the range from $0.02 \mathrm{mg} / \mathrm{kg}$ to 0.25 $\mathrm{mg} / \mathrm{kg}$.

Arafa et al. (2014) studied heavy metals (lead, cadmium, zinc, copper and iron) levels in milk and milk products collected from farms, individual farmers and dairy shops in Beni-Suef governorate, Egypt, and evaluate the potential health risks of metals to humans via consumption of milk and dairy products. $\mathrm{Pb}$ concentration in all samples exceeded the maximum permissible limit established by codex standard.

The aim of this study is to investigate and determine heavy metals ( $\mathrm{Pb}, \mathrm{Cd}, \mathrm{Cu}, \mathrm{Zn})$ in some market milk to estimate the limitation of their concentration for human uses, and this by collecting the samples at three validity time stages, first stage (the start of validity date),second stage ( the middle of validity date), and the third stage (the expiry date).

\section{Material and Methods}

\section{2- MATERIALS AND METHODS}

\subsection{Working reagents and standard solutions}

All the chemicals, standard solution and reagents used were of analytical grade Merck and Sigma-Aldrich grade.

\subsection{Milk sample Collection}

Total 18 samples of milk of different companies (Brand1 and Brand2) were collected from different market locations and retail stores in Qena city Egypt. Packing materials of the samples were cardboard paper, and glass bottle. All samples were collected at three stages of validity, first stage (the start of validity date), second stage ( the middle of validity date), and the third stage (the expiry date).

\subsection{Digestion of milk samples}

Microwave digestion system (Microwave Pressure Digestion, speed wave four DAP-60s, Berghof Products Instruments, Germany) was used for digestion of milk samples (Brand1 and Brand2) samples. $5 \mathrm{ml}$ of the milk sample was added into the digestion vessel to $5 \mathrm{ml}$ of $65 \%$ $\mathrm{HNO}_{3}$ and $1.0 \mathrm{ml} 30 \% \mathrm{H}_{2} \mathrm{O}_{2}$. The mixture was shacked carefully with clean Teflon, then the sample was put under fume hood for 20 min until vapors was ended, then the vessels were closed and heated in the microwave oven with the following programs in Table (1). After finishing of digestion in the microwave the tubes were taken to gas hood and was waiting until and the end of vapors, after then the obtained sample solution was completed to $25 \mathrm{ml}$ in measuring flask by deionized water.

Table 1: The programs of microwave oven for heating and digestion of milk samples.

\begin{tabular}{|l||c||c||c||c|}
\hline Step & 1 & 2 & 3 & 4 \\
\hline \hline T $\left[{ }^{\circ} \mathrm{C}\right]$ & 145 & 170 & 190 & 50 \\
\hline P [bar] & 50 & 50 & 0 & 0 \\
\hline Ta [min.] & 2 & 5 & 2 & 1 \\
\hline Time [min] & 5 & 10 & 15 & 10 \\
\hline Power [\%] & 40 & 40 & 40 & 0 \\
\hline
\end{tabular}

Where: $\mathrm{T}=$ temperature; $\mathrm{P}=$ pressure $; \mathrm{Ta}=$ minimum time for digestion; Time $=$ maximum time for digestion. 


\subsection{Analytical Techniques}

A flame atomic absorption spectrophotometer (Model 3110 Perkin- Elmer) equipped with digital and direct concentration readout and an air-acetylene burner was used for the element determinations. The instrumental parameters were those recommended by the manufacture. The light source used was a hollow cathode lamp for $\mathrm{Cd}^{2+}, \mathrm{Cu}^{2+}, \mathrm{Fe}^{2+}, \mathrm{Pb}^{2+}$, and $\mathrm{Zn}^{2+}$ which used at their recommended wave length and current.

\section{RESULTS AND DISCUSSION}

3.1. Heavy metal concentration in the different stages of Brand1 and Brand 2 milk samples In the present study, the concentration range of heavy metals $\mathrm{Cd}^{2+}, \mathrm{Cu}^{2+}, \mathrm{Fe}^{2+}, \mathrm{Pb}^{2+}$ and $\mathrm{Zn}^{2+}$ $(\mathrm{mg} / \mathrm{L})$ in Brand1 and Brand2 samples have been shown in the three stages of validity, first stage (the start of validity date), second stage ( the middle of validity date), and the third stage (the expiry date). The concentration data of heavy metals $\mathrm{Cd}^{2+}, \mathrm{Cu}^{2+}, \mathrm{Fe}^{2+}, \mathrm{Pb}^{2+}$ and $\mathrm{Zn}^{2+}$ $(\mathrm{mg} / \mathrm{L})$ are represented in Table (2), and Figures 1-3.

3.1.1. Heavy metal concentration in the first stage of Brand1 sample (the start of validity date):

From Table (2) and Figure (1), the range of $\mathrm{Cd}^{2+}, \mathrm{Cu}^{2+}, \mathrm{Fe}^{2+}, \mathrm{Pb}^{2+}$ and $\mathrm{Zn}^{2+}$ concentrations in Brand1 were ND-0.001, 0.021-0.284, ND-1.9, ND-0.035 and 3.93-4.56 mg/l, respectively, while the average for $\mathrm{Cd}^{2+}, \mathrm{Cu}^{2+}, \mathrm{Fe}^{2+}, \mathrm{Pb}^{2+}$ and $\mathrm{Zn}^{2+}$ concentrations in Brand1 were 0.00033, $0.1203,1.0266,0.01966$ and $4.276 \mathrm{mg} / \mathrm{l}$, respectively. So metal concentration in the first stage of Brand1 were in the order $\mathrm{Zn}>\mathrm{Fe}>\mathrm{Cu}>\mathrm{Pb}>\mathrm{Cd}$.

Salah et al. (2013) studied heavy metal residues $(\mathrm{Pb}, \mathrm{Cd}, \mathrm{Al}, \mathrm{Fe}, \mathrm{Se}$ and $\mathrm{Mn})$ in milk powder marketed in Dakahlia Governorate, Egypt and found that all examined samples of milk powder had $\mathrm{Pb}, \mathrm{Cd}, \mathrm{Fe}$, and $\mathrm{Mn}$ residues over the permissible limit, meanwhile, 96 and 58\% of the examined samples had Al and Sue levels above the permissible limit, respectively.

Gasmalla et al. (2013) found that cadmium level in milk powder was $4.062 \mathrm{mg} / \mathrm{l}$. Elbarbary and Hamouda (2015) reported Cd from 0.08 to $1.04 \mathrm{mg} / \mathrm{l}$.

3.1.2. Heavy metal concentration in the second stage of Brand1 sample (the middle of validity date)

Table (2) and Figure (2) show that the range of $\mathrm{Cd}^{2+}, \mathrm{Cu}^{2+}, \mathrm{Fe}^{2+}, \mathrm{Pb}^{2+}$ and $\mathrm{Zn}^{2+}$ concentrations in the second stage of the Brand1 were 0.001-0.002, 0.110-0.212, $0.01-1.6,0.001-0.005$ and $3.85-4.01 \mathrm{mg} / \mathrm{l}$, respectively, while the average for $\mathrm{Cd}^{2+}, \mathrm{Cu}^{2+}, \mathrm{Fe}^{2+}, \mathrm{Pb}^{2+}$ and $\mathrm{Zn}^{2+}$ concentrations were $0.0013,0.1543,0.8733,0.00236$ and $3.9233 \mathrm{mg} / \mathrm{l}$, respectively. So metal concentration in the second stage of Brand1 were in the order $\mathrm{Zn}>\mathrm{Fe}>\mathrm{Cu}>\mathrm{Pb}>\mathrm{Cd}$.Abdelkhalek et al. (2015) reported nearly similar results, as they found that the mean concentration of lead was $0.03 \mathrm{mg} / \mathrm{Kg}$ in examined skimmed milk powder in Mansoura city, Egypt.

3.1.3. Heavy metal concentration in the third stage of Brand 1 sample (the expiry date): Table (2) and Figure (3) show that the range of $\mathrm{Cd}^{2+}, \mathrm{Cu}^{2+}, \mathrm{Fe}^{2+}, \mathrm{Pb}^{2+}$ and $\mathrm{Zn}^{2+}$ concentrations in the third stage of the Brand1 were 0.001 - 0.003, 0.212 - 0.256, ND - 1.21, $0.0014-0.025$ and $4.03-4.21 \mathrm{mg} / \mathrm{l}$, respectively, while the average for $\mathrm{Cd}^{2+}, \mathrm{Cu}^{2+}, \mathrm{Fe}^{2+}, \mathrm{Pb}^{2+}$ and $\mathrm{Zn}^{2+}$ concentrations were $0.00166,0.2273,0.155,0.0124$, and $4.1166 \mathrm{mg} / \mathrm{l}$, respectively. So metal concentration in the third stage of Brand1 were in the order $\mathrm{Zn}>\mathrm{Fe}>\mathrm{Cu}>\mathrm{Pb}>\mathrm{Cd}$.

Malhat et al. (2012) reported that zinc concentrations in milk, kareish cheese, butter and rice pudding samples were in the ranges of $2.73-18.316,3.402-17.57,2.815-8.893$ and $0.888-6.094 \mathrm{mg} / \mathrm{l}$, 
respectively, with mean concentrations of $6.29 \pm 0.698,8.59 \pm 0.977,5.98 \pm 0.407$ and $3.01 \pm 0.446$ ppm, respectively.

Simsek et al. (2000) reported Fe contents in milk, kareish cheese, butter and rice pudding samples were in the ranges of $2.9619-45.6198,1.7633-14.7388,5.0693-13.14$ and $1.3208-3.438 \mathrm{mg} / \mathrm{l}$ with mean concentrations of $8.994 \pm 1.87,3.93 \pm 0.67,6.69 \pm 0.437$ and $2.04 \pm 0.17 \mathrm{mg} / \mathrm{l}$, respectively.

In conclusion: All examined milk samples of first, second and third stages having $\mathrm{Cd}^{2+}, \mathrm{Cu}^{2+}$, $\mathrm{Fe}^{2+}, \mathrm{Pb}^{2+}$ and $\mathrm{Zn}^{2+}$ concentrations don't exceed the permissible limits cited by Egyptian Standard 7136 (Egyptian Standards, 2010).

The permissible limits of heavy metals in milk recommended by Egyptian Standard 713 (Egyptian Standards, 2010) are 0.3 and $0.05 \mathrm{mg} / \mathrm{kg}$ for lead, and cadmium, respectively.

Table (2). Concentration range of heavy metals $(\mathrm{mg} / \mathrm{L})$ in Brand1 milk sample for first, second and third stage (the start of validity date, the middle of validity date, and the expiry date,respectively).

\begin{tabular}{|c|c|c|c|c|c|c|}
\hline \multirow{5}{*}{ 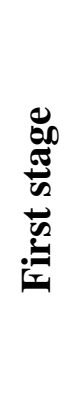 } & Brand1 & $\mathrm{Cd}^{2+}$ & $\mathrm{Cu}^{2+}$ & $\mathrm{Fe}^{2+}$ & $\mathbf{P b}^{2+}$ & $\mathbf{Z n}^{2+}$ \\
\hline & Sample1 & ND & 0.284 & 1.18 & 0.035 & 4.34 \\
\hline & Sample2 & 0.001 & 0.021 & 1.9 & 0.024 & 4.56 \\
\hline & Sample3 & ND & 0.056 & ND & ND & 3.93 \\
\hline & Average & 0.00033 & 0.1203 & 1.0266 & 0.0196 & 4.276 \\
\hline \multirow{4}{*}{ 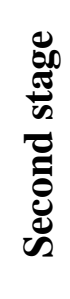 } & Sample1 & 0.002 & 0.212 & 1.01 & 0.005 & 4.01 \\
\hline & Sample2 & 0.001 & 0.110 & 1.6 & 0.001 & 3.85 \\
\hline & Sample3 & 0.001 & 0.141 & 0.01 & 0.0011 & 3.91 \\
\hline & Average & 0.00133 & 0.15433 & 0.8733 & 0.0023 & 3.9233 \\
\hline \multirow{4}{*}{ 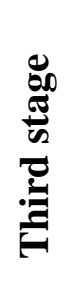 } & Sample1 & 0.003 & 0.214 & 1.10 & 0.025 & 4.11 \\
\hline & Sample2 & 0.001 & 0.212 & 1.21 & 0.011 & 4.03 \\
\hline & Sample3 & 0.001 & 0.256 & ND & 0.0014 & 4.21 \\
\hline & Average & 0.0016 & 0.2273 & 1.155 & 0.0124 & 4.1166 \\
\hline
\end{tabular}

$\mathrm{ND}=$ Not detected 


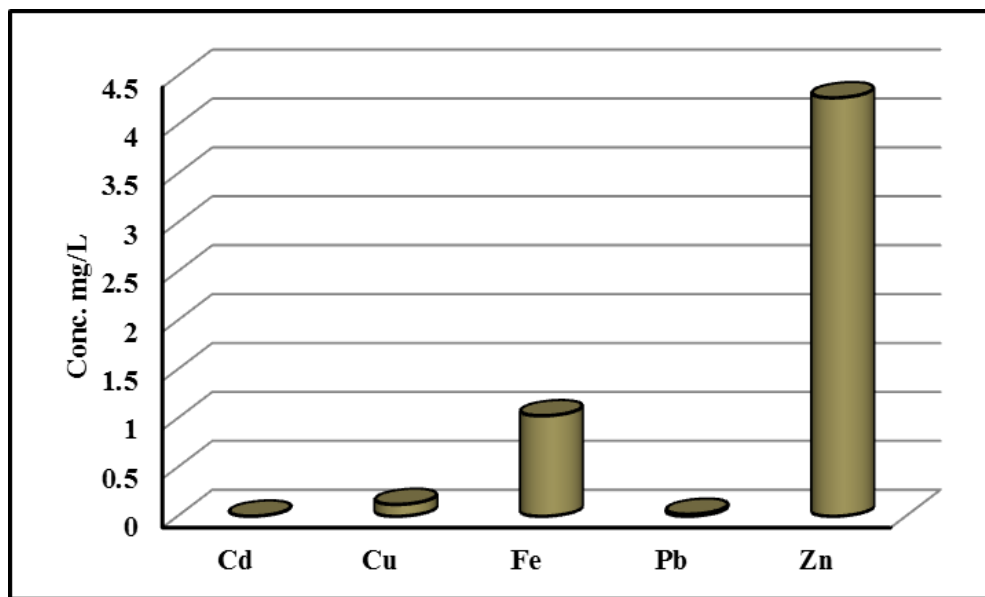

Fig. (1): Average metal concentration in the first stage of Brand1.

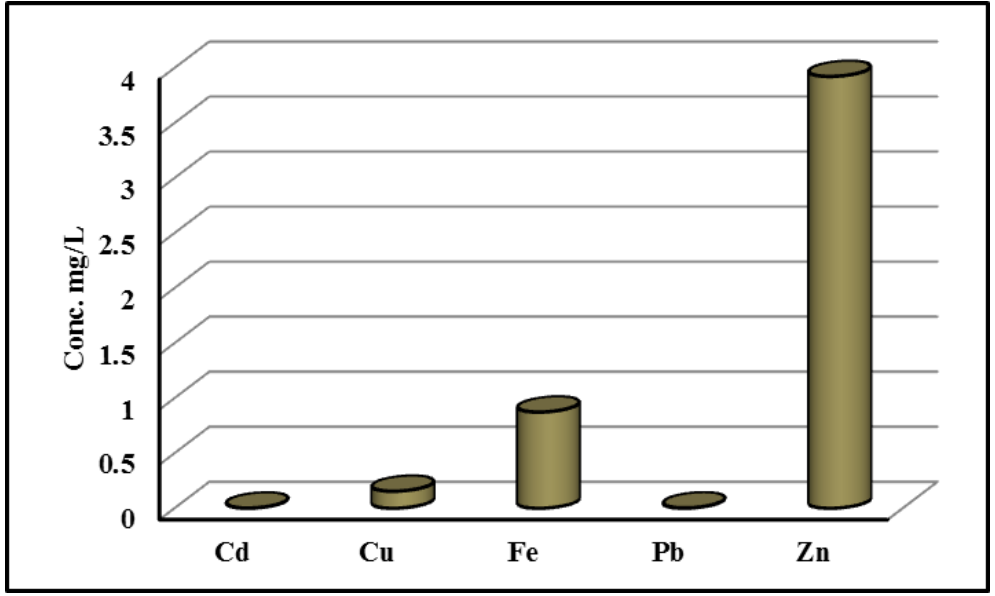

Fig. (2): Average metal concentration in the second stage of Brand1

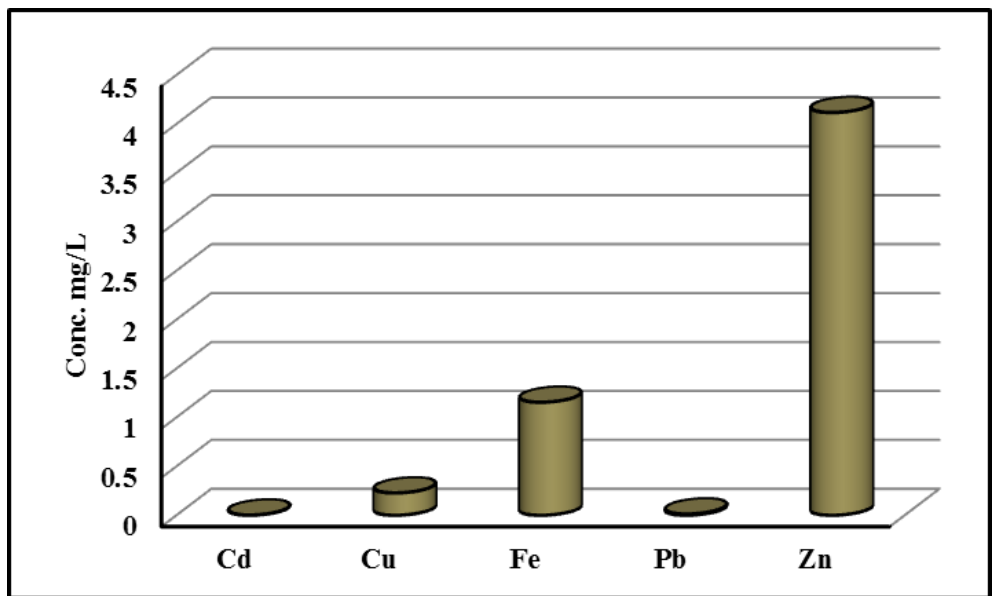

Fig. (3): Average metal concentration in the third stage of Brand1. 


\subsubsection{Comparison of heavy metal concentration between the three stages of Brand1 sample}

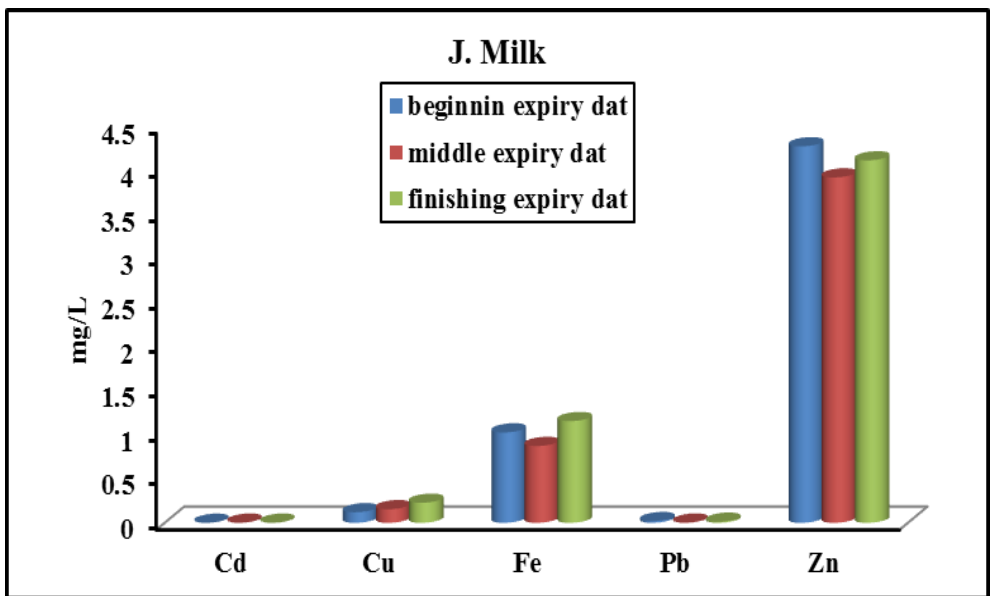

Fig. 4: The average metal concentration in the three stages of Brand1 sample (the start of validity date, the middle of validity date, and the expiry date).

Figure (4) shows that zinc concentration in all the three stages was higher than the other metals $(\mathrm{Cd}, \mathrm{Cu}, \mathrm{Fe}$ and $\mathrm{Pb})$. There is no significant difference in metal concentration between the three stages. Elbagermi et al. (2020) reported that e zinc is the highest detected heavy metal in all milk samples(pasteurized and long-life cow milk)

\subsection{Heavy metal concentration in the different stages of Brand2 samples}

3.2.1. Heavy metal concentration in the first stage of Brand2 sample (the start of validity date):

Figure (5) and Table (3) show that the range of $\mathrm{Cd}^{2+}, \mathrm{Cu}^{2+}, \mathrm{Fe}^{2+}, \mathrm{Pb}^{2+}$ and $\mathrm{Zn}^{2+}$ concentrations in Brand2 were ND - 0.001, $0.027-0.186,2.35-2.8,0.001-0.14$ and 3.9-5.0 mg/l, respectively, while the average for $\mathrm{Cd}^{2+}, \mathrm{Cu}^{2+}, \mathrm{Fe}^{2+}, \mathrm{Pb}^{2+}$ and $\mathrm{Zn}^{2+}$ concentrations in Brand2 were 0.0003, $0.1566,2.5,0.0513$ and $4.566 \mathrm{mg} / \mathrm{l}$, respectively. So metal concentration in the first stage of Brand 2 was in the order: $\mathrm{Zn}>\mathrm{Fe}>\mathrm{Cu}>\mathrm{Pb}>\mathrm{Cd}$.

Elbarbary and Hamouda (2015) detected lead in a concentration of $1.61 \mathrm{mg} / \mathrm{l}$ in examining whole milk samples with a minimum of 0.59 and a maximum $3.16 \mathrm{mg} / \mathrm{l}$.

3.2.2. Heavy metal concentration in the second stage of Brand 2 sample (the middle of validity date)

From Fig. (6) and Table (3) it was shown that the range of $\mathrm{Cd}^{2+}, \mathrm{Cu}^{2+}, \mathrm{Fe}^{2+}, \mathrm{Pb}^{2+}$ and $\mathrm{Zn}^{2+}$ concentrations in Brand2 were Nd-ND, $0.17-0.55,2.15-2.9, \mathrm{ND}-0.015$ and $4.25-4.6 \mathrm{mg} / \mathrm{l}$, respectively, while the average for $\mathrm{Cd}^{2+}, \mathrm{Cu}^{2+}, \mathrm{Fe}^{2+}, \mathrm{Pb}^{2+}$ and $\mathrm{Zn}^{2+}$ concentrations in Brand2 were $0.000,0.4133,2.43,0.0171$ and $4.4166 \mathrm{mg} / \mathrm{l}$, respectively. So metal concentration in the second stage of Brand 2 was in the order: $\mathrm{Zn}>\mathrm{Fe}>\mathrm{Cu}>\mathrm{Pb}>\mathrm{Cd}$.

Nearly similar results were reported by Abdelkhalek et al. (2015). Lower findings were reported by Abdulkhaliq et al. (2012) who detected cadmium with a mean concentration of $0.00001 \mathrm{mg} / \mathrm{l}$ and by O'Keeffe et al. (2001) who could not detect cadmium in any of the examined skimmed milk samples.

3.2.3. Heavy metal concentration in the third stage of Brand 2 sample (the expiry date): Fig. (7) and Table (3) show that the range of $\mathrm{Cd}^{2+}, \mathrm{Cu}^{2+}, \mathrm{Fe}^{2+}, \mathrm{Pb}^{2+}$ and $\mathrm{Zn}^{2+}$ concentrations in Brand2 were Nd-ND, $0.20-0.50,2.15-2.9,0.012-0.036$ and $4.05-4.36 \mathrm{mg} / \mathrm{l}$, respectively, 
while the average for $\mathrm{Cd}^{2+}, \mathrm{Cu}^{2+}, \mathrm{Fe}^{2+}, \mathrm{Pb}^{2+}$ and $\mathrm{Zn}^{2+}$ concentrations in Brand2 were 0.000, 0.3966, 2.4533, 0.000 and $4.176 \mathrm{mg} / \mathrm{l}$, respectively. So metal concentration in the third stage of Brand2 was in the order: $\mathrm{Zn}>\mathrm{Fe}>\mathrm{Cu}>\mathrm{Pb}>\mathrm{Cd}$.

Abdelkhalek et al. (2015) reported nearly similar results, as they found that the mean concentration of lead was $0.03 \mathrm{mg} / \mathrm{kg}$ in examined skimmed milk powder in Mansoura city, Egypt. While Abdulkhaliq et al. (2012) reported that the mean concentration of lead was 0.002 $\mathrm{mg} / \mathrm{kg}$ in examined skimmed milk powder in Ramallah City, Palestine. On the other hand, Gasmalla et al. (2013) detected lead in whole milk powder and children dry milk with a mean concentration of 3.3250 and $3.64375 \mathrm{mg} / \mathrm{kg}$, respectively.

The permissible limits of heavy metals recommended by Egyptian Standard 7136 (Egyptian Standards, 2010) are 0.3 , and $0.05 \mathrm{ppm}$ for lead, and cadmium, respectively. The maximum concentration of lead and cadmium in all samples examined in the present study did not exceed the permissible limits.

Table (3). Concentration range of heavy metals $(\mathrm{mg} / \mathrm{L})$ in Brand 2 sample for first, second and third stage (the start of validity date, the middle of validity date, and the expiry date,respectively).

\begin{tabular}{|c|c|c|c|c|c|c|}
\hline Stage & Brand2 & $\mathrm{Cd}^{2+}$ & $\mathrm{Cu}^{2+}$ & $\mathrm{Fe}^{2+}$ & $\mathbf{P b}^{2+}$ & $\mathrm{Zn}^{2+}$ \\
\hline \multirow{4}{*}{ 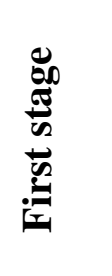 } & Sample1 & 0.001 & 0.186 & 2.8 & 0.14 & 4.8 \\
\hline & Sample2 & ND & 0.014 & 2.35 & 0.013 & 3.9 \\
\hline & Sample3 & ND & 0.27 & 2.35 & 0.001 & 5.0 \\
\hline & Average & 0.0003 & 0.1566 & 2.5 & 0.0513 & 4.566 \\
\hline \multirow{4}{*}{ 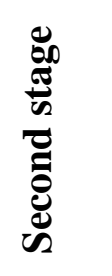 } & Sample1 & $\mathrm{Nd}$ & 0.55 & 2.24 & 0.015 & 4.25 \\
\hline & Sample2 & $\mathrm{Nd}$ & 0.17 & 2.15 & $\mathrm{Nd}$ & 4.6 \\
\hline & Sample3 & $\mathrm{Nd}$ & 0.52 & 2.9 & 0.0365 & 4.4 \\
\hline & Average & 0 & 0.4133 & 2.43 & 0.0171 & 4.416 \\
\hline \multirow{4}{*}{ 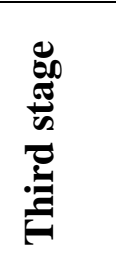 } & Sample1 & $\mathrm{Nd}$ & 0.50 & 2.31 & 0.012 & 4.05 \\
\hline & Sample2 & $\mathrm{Nd}$ & 0.20 & 2.15 & 0.014 & 4.12 \\
\hline & Sample3 & $\mathrm{Nd}$ & 0.49 & 2.9 & 0.036 & 4.36 \\
\hline & Average & 0 & 0.3966 & 2.4533 & 0.0206 & 4.176 \\
\hline
\end{tabular}




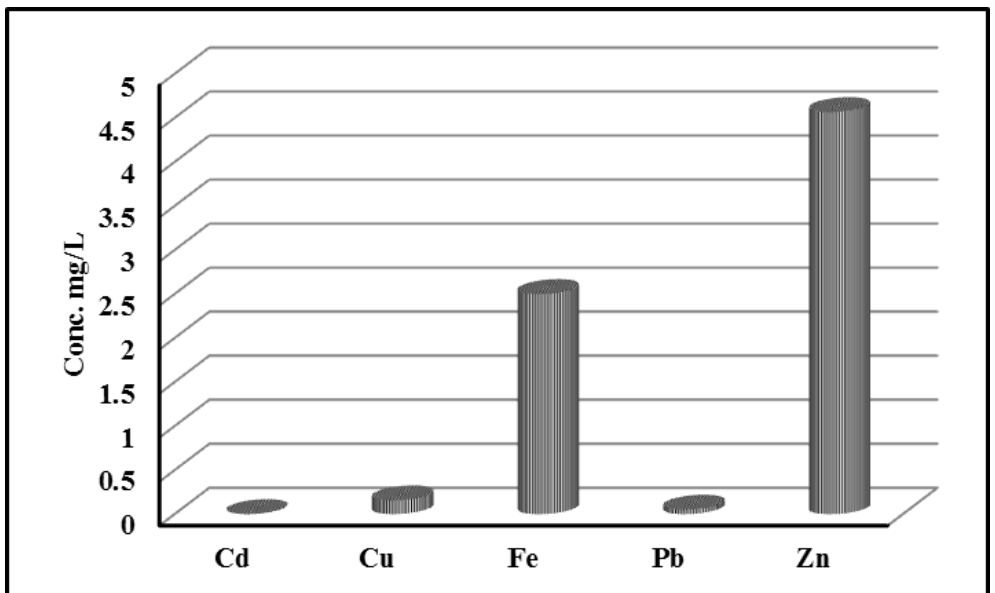

Fig. (5): Average metal concentration in the first stage of Brand2.

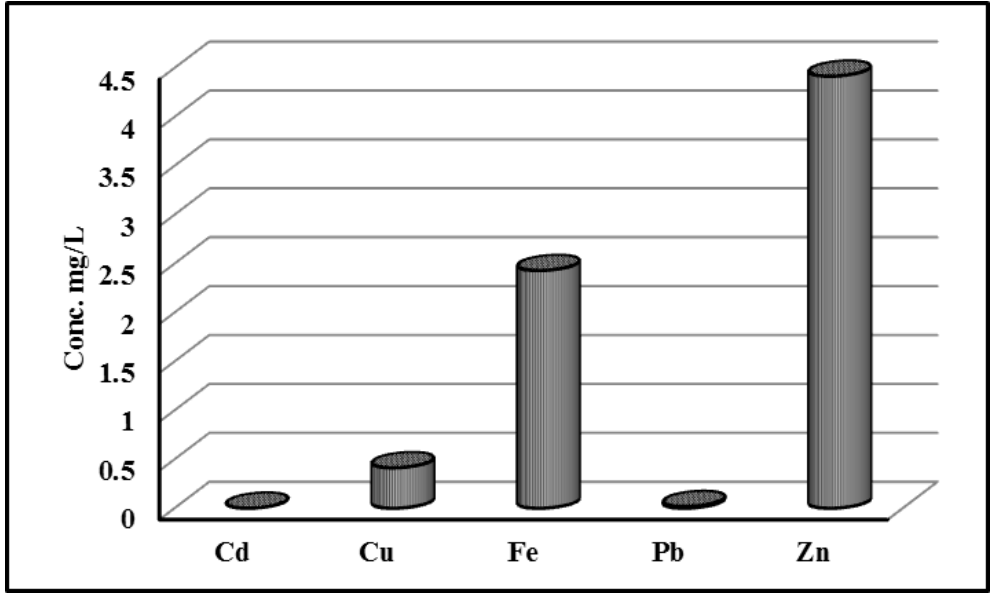

Fig. (6): Average metal concentration in the second stage of Brand2.

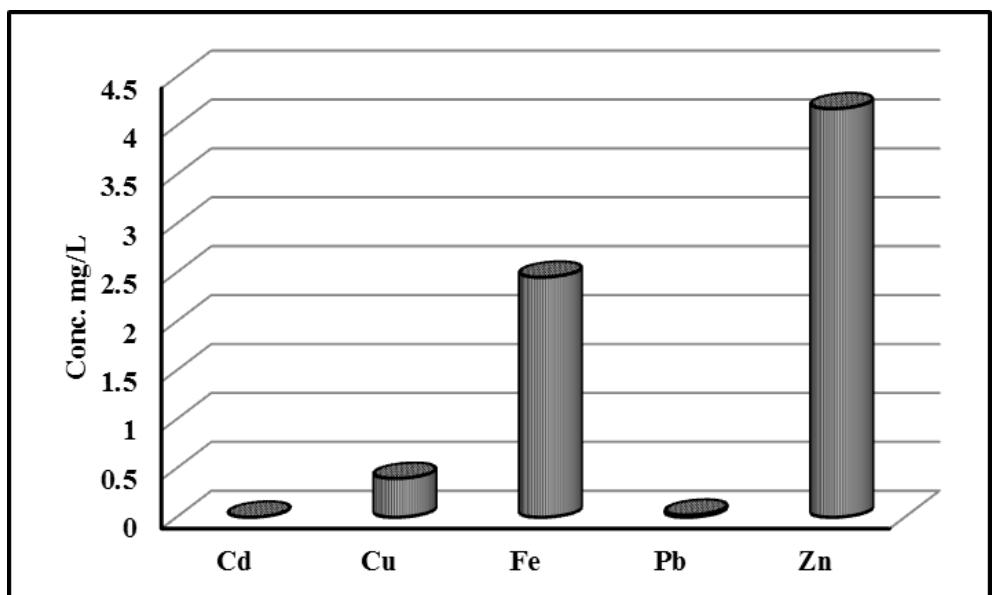

Fig. (7): Average metal concentration in the third stage of Brand2. 


\subsubsection{Comparison of heavy metal concentration between the three stages of Brand 2 sample}

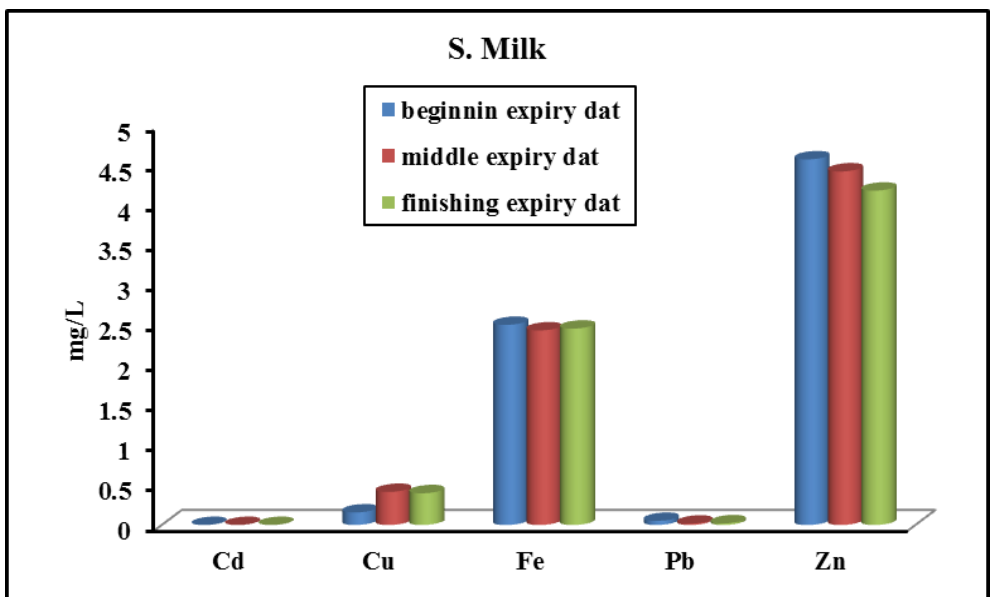

Fig. 8: The average metal concentration in the three stages of Brand2 sample (the start of validity date, the middle of validity date, and the expiry date).

Figure 8, show that zinc concentration in all the three stages was higher than in the other stages. There is no significant difference in metal concentration between the three stages.

\section{Conclusion}

The present work is concerned with the estimation and detection the concentration of some heavy metals ( $\mathrm{Pb}, \mathrm{Cd}, \mathrm{Cu}, \mathrm{Zn}$ and $\mathrm{Fe}$ ) in different periods of expert dates (the start of validity date, the middle of validity date, and the expiry date) of some market milk samples to estimate the limitation of their concentration for human uses. The estimated metals were measured by atomic absorption spectrophotometer. The concentration of the studied heavy metals $(\mathrm{Cd}, \mathrm{Cu}, \mathrm{Fe}, \mathrm{Pb}$ and $\mathrm{Zn}$ ) in the 3 stages of milk samples were lower than the Egyptian Standard of food and WHO standard.

\section{References}

Abdelkhalek, A.; Elsherbini, M. and Gunbaej, E.E. (2015): Assessment of heavy metals residues in milk powder and infant milk formula sold in Mansoura city, Egypt. Alexandria J Vet Sci.; 47(1):71-77.

Abdulkhaliq, A.; Swaileh, K.M.; Hussein, R.M. and Matani, M. (2012): Levels of metals (Cd, Pb, $\mathrm{Cu}$ and $\mathrm{Fe}$ ) in cow's milk, dairy products and hen's eggs from the West Bank, Palestine. International Food Research Journal. 19(3):1089-1094.

Alimardan M.; Ziarati, P. and Moghadam, R.J. (2016): "Adsorption of Heavy Metal Ions from Contaminated Soil by B. integerrima Barberry". Biomedical and Pharmacology Journal 9.1: 169-175.

Arafa, M., Walaa A.M.; Nour El-Houda Y. and Hassan (2014): Heavy metals and trace elements levels in milk and milk products. Food Measure (2014) 8:381-388.

Azami, J.; Moradpour, H. and Kiani, M.N. (2017): “A Review of Biotic Indices for Heavy Metals in Polluted Environment". Human and Environment 15. 13-24.

Egyptian standard (ES.7136)(2010): Maximum level contaminants in foodstuffs. ESNO.7136/2010. Cairo, Egypt. 
Elbagermi Mohamed Atiga, Antisar Abdulmajid Bin Haleem, Khaled Muftah Elsherif (2020): Evaluation of essential and heavy metal levels in pasteurized and long-life cow milk. International Journal of Advanced Chemistry, 8 (1), 6-14

Elbarbary, H.A. And Hamouda, A.F. (2015): Assessment of some trace elements in some dairy products and table eggs retailed in Egyptian markets. Alexandria Journal of Veterinary Sciences; 47:175 - 182.

FAO/WHO (1999): (Evaluation of certain food additives and contaminants) (Forty-ninth report of the Joint FAO/WHO Expert Committee on Food Additives). WHO Technical Report Series, No. 884, p 7.

FAO/WHO (2000a): (Evaluation of certain food additives) (Fifty-first report of the Joint FAO/WHO Expert Committee on Food Additives). WHO Technical Report Series, No. 891, p 17.

FAO/WHO (2000b): (Evaluation of certain food additives and contaminants) (Fifty-third report of the Joint FAO/WHO Expert Committee on Food Additives). WHO Technical Report Series, No. 896, p $11 f$.

Francisco De la Cueva, Alexandra N., Byron H. P. T., Eduardo A. (2021): Presence of heavy metals in raw bovine milk from Machachi, Ecuador.LaGranja, 33(1), 21-30

Fukuda, K. (2015): Food safety in a globalized world. Bull. WHO, 93, 212.

Gasmalla, M.A.; Khadir, E.K.; Musa, A.; Aboshora, W and Zhao, W. (2013): Evaluation of some physicochemical parameters of three commercial milk products. PAK J FOOD SCI. 23(2):62-65.

Malhat, F.; Hagag, M.; Saber, A. and Fayz, A. (2012): Contamination of cows milk by heavy metal in Egypt. Bull. Environ. Contam. Toxicol. 88, 611-613.

Mridha, Z.U. (2013): Food safety-A global concern. Bangladesh J. Med.Biochem. 4(2):3-5.

O'Keeffe, M. (2001): Food Residue Database Newsletter, June. The National Food Centre, Teagasc. $4 \mathrm{p}$.

Raikwar, M.K.; Kumar, P.; Singh, M. and Singh, A. (2008): Toxic effect of heavy metals in livestock health. Vet. World 1(1):28-30.

Salah, F.A.A.E., Esmat, I.A. and Mohamed, A.B (2013) Heavy metals residues and trace elements in milk powder marketed in Dakahlia Governorate. International Food Research Journal 20(4): 1807-1812.

Sarsembayeva, N.B.; Abdigaliyeva, T.B.; Utepova, Z.A.; Biltebay, A.N. and Zhumagulova, S. Zh. (2020): Heavy metal levels in milk and fermented milk products produced in the Almaty region, Kazakhstan. Vet World. 2020 Apr; 13(4): 609-613.

Shahriar, S.M.S.; Akther, S.; Akter, F.; Morshed, S.; Alam, M.K.; Saha, I.; Halim, M.A. and Hassan, M.M. (2014): Concentration of Copper and Lead in Market Milk and Milk Products of Bangladesh. ISSN: 2299-3843, Vol. 27, pp 56-63.

Simsek, O.; Gultekin, R.; Oksuz, O. and Kurultay, S. (2000): The effect of environmental pollution on the heavy metal content of raw milk. Nahrung 44, $360-363$. 
Viswanathan, S.; Radecka, H. and Radecki (2009): J. Electrochemical biosensors for food analysis. Mon. Chem. 140, 891e899.

WHO (2000): Lead, In: Safety Evaluation of Certain Food Additives and Contaminants, FiftyFifth Meeting of the Joint FAO/WHO Expert Committee on Food Additives (JECFA), Geneva: WHO Food Additives Series, 44, World Health Organization, Geneva, 273312.

Ziarati, P.; Moghimi, S.; Arbabi-Bidgoli, S. and Qomi, M. (2012): "Risk Assessment of Heavy Metal Contents (Lead and Cadmium) in Lipsticks in Iran". International Journal of Chemical Engineering and Applications 3.6., 450-452. 